\title{
Research on Changes of Spatial Structure Genotype of a Former Artillerymen' Military Town of Kaunas Fortress
}

\author{
Kęstutis Zaleckis, Aušra Mlinkauskienè, Nijolè Steponaitytė \\ Kaunas University of Technology, Faculty of Civil Engineering and Architecture, Lithuania
}

\begin{abstract}
Immovable cultural heritage creates a background for sustainable cultural development of cities. As a cultural artefact, it appears in two-fold situation in the above-mentioned context. Firstly, the continuity of the valuable features as carriers of cultural content should be preserved. Secondly, the possibility of the evolution (functional, spatial or social) of the object should be assured. Now the valuable features of the immovable cultural heritage are described in a static, quantitative ways with focus on phenotype, e.g. spatial volume, place, details of architectural style, number and places of windows, etc. Such type of description without any argumentations is practically closing any possibilities for further evolution of the protected objects. It is especially true if we speak about urban valuable structures. The authors of the article present a proposal for dynamic, genotype oriented modelling of the possible evolution of the former military town of Kaunas Fortress as an example of immovable urban cultural heritage. The model is based on the evaluation of changes in the cognition of urban structure with presentation of complex numerical values. Research included the following parts: historical urban development analysis of heritage territory, current state analysis, investigation and modelling of territory spatial structure genotypic changes. The results of the presentation demonstrate the limitations and subjectivity of the present system of description of valuable features of the objects of immovable cultural heritage and present the possible way for the improvement of the situation.
\end{abstract}

Key words: cultural heritage, valuable properties, fortress system, space syntax, cognitive frame

Introduction

The article was prepared on the basis of the research focussed on evaluation and prediction changes of valuable features of immovable cultural heritage. The study was ordered to be carried out by Juozas Vitkus Engineering Battalion in order to find out if the planned construction of prefabricated structures will not affect the historical spatial genotype of the protected urban structure. The investigated territory is a part of the complex of Artillery barrack buildings of Kaunas Fortress, the task of the research was formed on the base of the statement of the Department of Cultural Heritage under the Ministry of Culture "...on the part of the plot at Kareiviniu St. 9, Kaunas, that enters the territory of a cultural heritage object protected by state, construction works that do not damage the valuable properties of the object, are allowed. The new construction needs to be based on historical research, proving that the historic building actually was on the planned site of construction ...".

Article 19(2) of the Law on Protection of Immovable Cultural Heritage of the Republic of Lithuania states that "In an object protected for public knowledge and use, territory thereof, at a site, it shall be prohibited: to destroy or to otherwise damage the valuable properties specified in the certificate of immovable cultural property; in the territory or protection zone, to build the structures likely to eclipse the object or objects of cultural heritage by height, size or appearance and hinder survey thereof; to destroy or damage monument

boards, information stands of the immovable cultural property or the boundary marks of the territory of an object or site of cultural heritage". Article 19(4) of this Law also states that "In an object protected for public knowledge and use, the construction operations diminishing valuable properties shall be prohibited: adaptation of the object of cultural heritage for the uses other than specified in the certificate of immovable cultural property; increase of the intensity of the use of protected structures the building of extensions to buildings, additional floors, the equipment of new mansards, the formation of a new planned structure and otherwise destroying signs of authenticity".

Taking into account the aforementioned conditions, the aim of the research work is as follows: to carry out the historical research, as well as research on the current state and spatial structure genotype, on immovable cultural heritage and ascertain whether: 1 . the new building will not affect the valuable properties of the complex, 2. will not obscure cultural heritage objects or their visibility; 3 . will not violate the spatial structure of the territory. In response to the aim of the research, the following studies were carried out: analysis of historic - urban development of heritage object; specification and evaluation of current state and valuable properties of the complex; investigation and modelling of changes of spatial structure genotype of a former artillerymen' military town of Kaunas Fortress. The research was based on bottom-up or predictive 


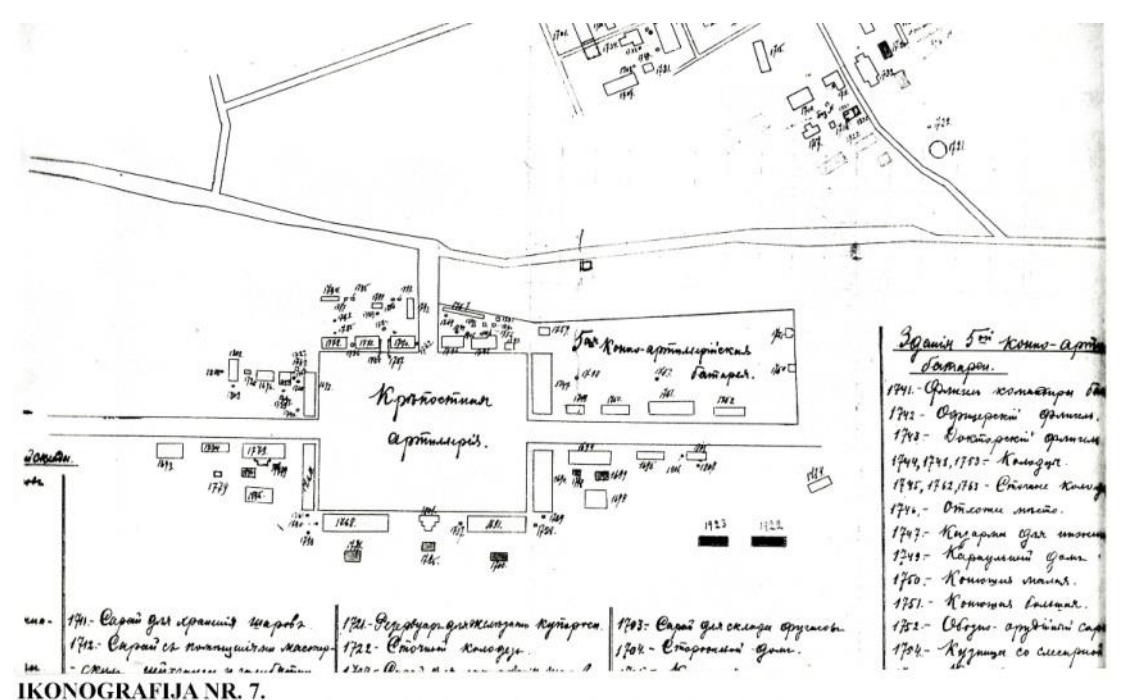

Fig. 1. A fragment from a plan of military town of department of artillery and aeronautics of Aukštoji Panemune $\sim 1912$ (РГВИА, ф. 13148, on. I, д.) [1; Iconography No. 7, taken from N. Steponaityte’ personal archive]

modelling approach while using the Space Syntax models in order to compare past, present and predicted spatial features of the protected urban area in terms of its perception and potential scenarios of space usage. Besides the practical objective to evaluate possible transformations of the investigated object, the research aims to demonstrate and prove possibility to describe valuable features of architectural and urban cultural heritage while using quantitative methods.

\section{Analysis of Historic - Urban Development of the Heritage Object}

Aukštoji Panemunè complexes of military buildings. In 1894, the state bought folwarks (similar to small mansions,- translator's note) near Aukštoji Panemune and Frendzelhof; Mansion of Aukštoji Panemune and the town itself became the property of the Russian Ministry of War. Originally, military roads were built, and the main street of the town (Vaidotas street) became the military highway. In 1895-1899, three big military towns developed in Aukštoji Panemunè, 73 military objects were built barracks, houses for officers and administrative staff, warehouses, stables, workshops, cellars, other outbuildings. Construction continued at the beginning at 20th century.

In the territory of former mansion of Aukštoji Panemune, near Nemunas, a fortress company of pioneers was established. In 1911, the following buildings of the company were marked on the plan: barracks, a warehouse for shells, stables, officers' house, registry and a commander's apartment, sauna with workshops and guardrooms, servants' house with a laundry, and cellars.

The department of aeronautics was being created close to the river Semena; it contained barracks, workshops with pigeonry, warehouse for sulphuric acid, warehouse for trains, the house where the head of the department lived (formerly the house where the owner of the manor lived), stables, coal warehouse, smithery, a hangar for lacquering air balloons, reservoir, various warehouses and small buildings. There were also plans to build hangars for airplanes and air balloons, garages for cars, but there were not enough time to implement those projects (Fig. 1). Here, in 1912-1923, the aerodrome of Kaunas Fortress has already been operating. The territory of the aerodrome was on the right bank of River Semena, which is approximately, where Birutes street passes now. The aerodrome at that time was simply a flattened meadow.

After World War I, the units of the Lithuanian Army were deployed at Aukštoji Panemunè. In 1936, a motorized anti-aircraft protection team has been created.

A warehouse complex for artillery was established to the northeast of military towns. It consisted of an intermediate warehouse for powder, a warehouse for wet and gun cotton, a drying room, a laboratory, a gendarmes' homestead.

Complex of barrack buildings of Kaunas Fortress Artillery. A large fortress artillery barrack complex was built to the south of Aukštoji Panemune. The place for artillerists was chosen at the foot of the slope of the Nemunas valley. The slope was supposed to serve as a natural obstacle at the southwest side. The slope was also needed for the installation of shooting-ranges. In the field, which was intended to be a place for a Fortress, on the terrace of an upper valley, on the southeast side of the slope, a large artillery ground with obstacles and trenches was erected. The territory of the polygon extended as far as the Fourth Fort. The field was also intended to be used as one of the aerodromes of the fortress.

The complex was built according to the strict principles of geometric planning, its territory 


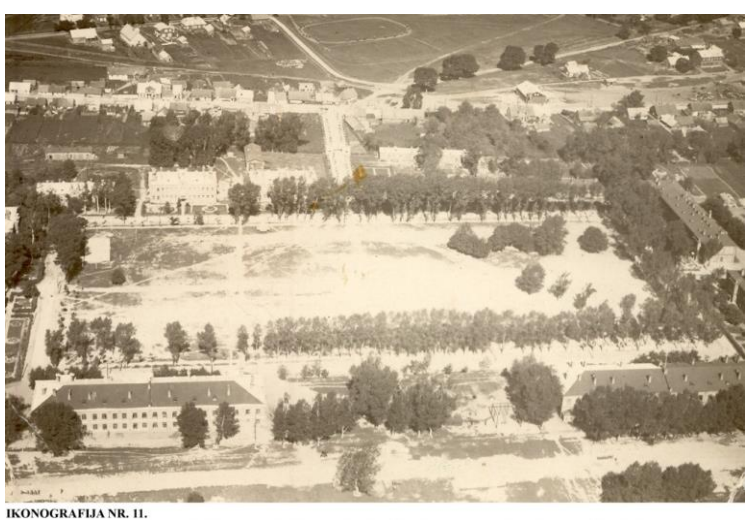

Fig. 2. Aukštoji Panemune. Barracks of the Great Duke Kestutis' $5^{\text {th }}$ Infantry Regiment. Kaunas, 20 century, 1920-1930

[2; Iconography No. 11, funds of Vytautas the Great War Museum. Fa-14045]

extended parallel to the slope from the current Plytinè Street to the cemetery of Aukštoji Panemunè. The buildings were being located around a large rectangular square intended for paradestrainings, and near three streets that vertically meet together at that exact place. In the south-west, south and east side of the square a four brick two-storey barracks (that were made of bricks) were built, as well as a guard-house and warehouses for guns; on the north and west side there was doctor's house, canteen, sauna, one-two-storey masonry blocks of flats for officers, with warehouses, cellars and other outbuildings.

A narrow railway line of the Fortress that reached the barracks was built, which passed along the slope of Nemunas Valley from military railway station at Žemoji Freda (near railway bridge over Nemunas) to the north-eastern edge of artillery building complex (almost to the cemetery).

The plan of 1980 lists primary buildings: four barracks, each for 2 companies, canteen with kitchen and pantries, cellar for storing food, house for heads of 8 companies, their stables with pantries, cellar for storing food and officers' laundry. In 1911, the following buildings are marked as present in a plan of $5^{\text {th }}$ horse artillery: a commander's house, officers' house, doctor's house, two storey barracks, guardhouse, small stables, big stables, warehouse for gun carriages, smithery, hospital for horses, house for officers' servants, a cellar, cooling room; stables are also designed, as well as sauna, laundry, emergency warehouses with reserves, woodsheds, cooling rooms, workshops, three houses for the commander of the battalion and young officers, laundry for officers. Two large shooting-ranges were installed, surrounded by terraces.

The complex of the present form and composition only formed on the eve of World War I. As the mobilization was launched, hiding places made of concrete were started to be built on the south side of the complex, on the slope of the valley. The data on how many of them there was supposed to be built was not found, but now the remains of 6 hiding places, which have been blown up, remained.

The buildings of the complex were of red brick, which was made by a masonry nearby. Officers' houses were built with warehouses, cooling rooms. Unlike in Žemieji Šančiai, masonry houses for officers and specialists were built instead of wooden ones. There were no wooden buildings in the entire territory of Aukštoji Panemunè. The facades of officers' houses are decorated with rather sophisticated brick details. The interior was also much more luxurious in comparison with the former military town of Žemieji Šančiai (Fig. 2).

The access roads and yards were paved with outdoor stones, while in Šančiai most of the access roads were paved with soil. As it was written in the press at the beginning of the 20th century, the barracks district in Žemieji Šančiai was known as being untidy and full of dust and mud.

There are drinking water wells and drainage wells in the territory. Water that ran from the slopes, which would run in ditches, and in the lower part would get into drainage wells and pipes, was a big problem. Underground drainage system has not been investigated.

After World War I, artillerymen of the Lithuanian Army settled here, they also enjoyed the natural situation and a ground mounted on top of the slope. During the interwar period there were no major changes, no new buildings were built. The railway was dismantled. During this period, an important building was built - concrete entrance gates decorated with the symbols of the Lithuanian Armed Forces.

In 1940s, the complexes of the Lithuanian Armed Forces throughout Lithuania were taken over by the Red Army.

During World War II, the German Army occupied many buildings.

After the war, the Red Army (later - the Soviet Army) took over again. Then intensive constructions began in the territory. As the tradition was continued here, artillerymen who needed a lot of room for various mechanisms settled here; massive masonry and assembleble concrete hangars were built for tanks and other mechanisms, as well as big workshops and garages. The buildings were placed without much attention to the historic urban structure.

In 1993, after the Soviet Army withdrew from Lithuania, the Lithuanian Armed Forces settled down in the complexes of military towns in Aukštoji Panemuné - a battalion of soldiers deployed in the south-western part of the city, residential houses remained next to the training ground, and the engineering battalion of General Juozas Vitkus settled on the north-eastern side. Many big buildings 
of Soviet era were demolished; most of them remained on the very north-eastern edge of the territory.

\section{The Specification and Assessment of the Current State of the Complex and its Valuable Properties}

According to the data of the Department of Cultural Heritage, the part of the plot under investigation entering the Kaunas Fortress Artillery complex of barrack buildings is registered in the Register of Real Heritage of the Republic of Lithuania [3]. This part of the complex is marked with symbol " $\mathrm{A}$ " and is located in the northern and north-eastern part of the investigated area (Fig. 3). The plot at Kareiviniu St. 9 covers not only the protected complex, but also the farming-production zone (about 55\%) which is unprotected and belongs to the technical park of the battalion.

Planned spatial layout of the territory. While studying the spatial layout of the territory, two morphological zones of different periods with different morphological types of layout reveal themselves. Morphological types are the historically formed parts of morphological zones where the distinctive planned structures of separate historical periods, the spatial compositions and the contingent of authentic, valuable properties that have exceptional properties of cultural value all remained. Part of the territory relevant to the research was formed during the Tsarist period, the other part - in the Soviet period. During the study of the layout of the territory, two morphological zones of different periods were distinguished with different morphological types of layout, where the layout of the buildings built in the Tsarist period is clearly geometrically structured. The layout of the buildings is strict and linear; two axes are formed, first - along the eastern edge of the main square of the complex, the second - going from the western boundary of the site with the reciprocal layout of the inner road. The structure of the layout formed later on, during the Soviet times, is free, formed without regard to the previous layout. These territories of a different period are also different from a functional point of view. The territory of the Tsarist period consists of administrative-residential buildings that define the main residential-community function of this zone. The territory that shaped during the Soviet period has buildings for production and farming, which respectively form the production function of this territory (technical park zone). The administrative zone of the battalion is intended for administrative and residential premises used for conscripts' accommodation, feeding, training, conferences and meetings. In this zone, trainings, lectures and cultural events for soldiers are organized. Both heavy (armoured) and passenger cars drive around in the technical park zone; the road

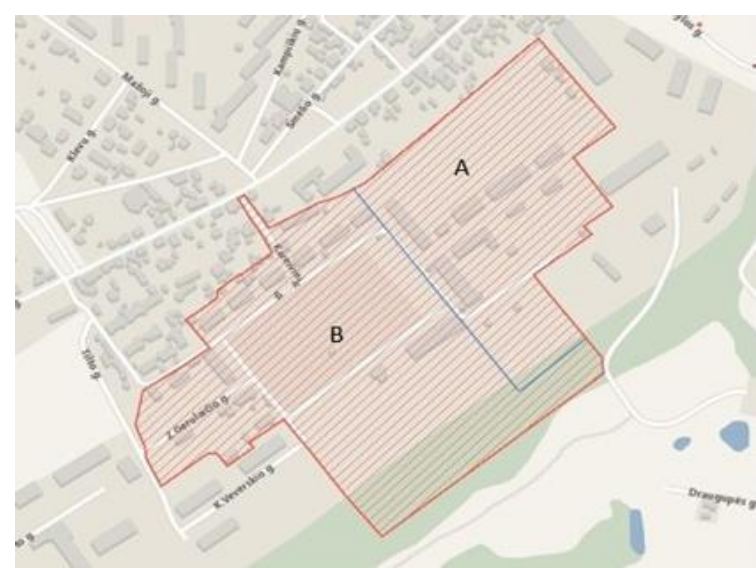

Fig. 3. Complex of barrack buildings of Kaunas Fortress Artillery. Explanation: $\boldsymbol{A}$ - part of the plot at Kareiviniu St. 9 that enters the territory of a protected object Kaunas Fortress Artillery complex of barrack buildings; $\boldsymbol{B}$ - the rest of the

Kaunas Fortress Artillery complex of barrack buildings [3]

infrastructure is unpaved, which is why there are a lot of dust, noise created by working machinery can constantly be heard; the soldiers are trained how to use engineering machinery and equipment, various operational materials are stored.

Visual expression of buildings and their current state. The visual expression of buildings is characterized by the individuality of buildings and the peculiarities of visual properties. The specific layout of the territory is determined by buildings of different periods. It is possible to distinguish three main periods: Tsarism, Soviet and Independent Lithuania. The architecture of Tsarist period enters the protected zone of the battalion and is mainly in the administrative functional territory. The buildings are built from red brick masonry, they are 1-3 storey high, with sloping roofs, the facades are distinguishable by decor and exterior pillars, as well as decorated cornices. The buildings of the Soviet period are built from masonry of white silicate bricks, the facades are without any decor elements, massive volumes and flat roofs can be distinguished. These are mostly garages, warehouses and repair workshops. The intervention of the Independence period is not significant. It is more associated with the renovation of buildings and reconstruction works. Auxiliary buildings such as transformers, etc., are refurbished by using facades of lightweight constructions and painting them dark green, which fit in the natural environment.

The originality and individuality of the territory is formed not only by buildings, but also by plantations and spaces for mass events, intended for outdoor events specifically, that cannot be obscured by buildings and planted with plantations. Other areas of the territory are moderately planted; cosy, semi-enclosed spaces are formed.

The current state of buildings of a complex. The current state is assessed taking into account the general physical state of the building, roof types, 
materiality and height. The physical state of the building is evaluated taking into account how wornout the building is: Good condition (the building is renovated or the physical damage that is already done does not exceed $25 \%$ ) - G, medium (repairs are necessary for the building, physical damage exceeds $50 \%$ ) - V and bad (structural changes are necessary for the building as it is worn-out by more than $75 \%$ ) - B. When assessing the current state of the buildings, the following types of roofs are distinguished: gable roofs - DV, hip roofs - KT and flat roofs - ST. When assessing the materiality of buildings, the following materials are distinguished: historical red brick masonry - RPL, brick masonry - PL, concrete/blocks/slab blocks BL, mixed constructions - MK. The height is provided indicating storeys including an attic $-2 \mathrm{M}$, or without an attic -2 .

The physical state of the buildings of Juozas Vitkus Engineer Battalion is good; however, the physical state of few of the buildings is mediocre. Both in the administrative-residential zone and in the technical park zone the buildings are being renovated and maintained. The renovation of historic buildings is carried out in compliance with heritage protection requirements, their valuable properties are not violated.

Description of valuable properties of an object. Importance level - regional; status - protected by state; type - immovable; structure of the heritage complex. The complex consists of: 1. Hospital for horses at complex of barrack buildings of Kaunas Fortress Artillery; 2. Farm building; 3 . Smithery; 4. Warehouse for guns; 5 . The big stables; 6 . The small stables; 7. Building serving other purposes; 8 The first building of the sauna; 9 . Stables; 10. Canteen; 11. First warehouse; 12-13. First and second barracks buildings; 14. Fragments of paving in the territory between stables (Tables 1-2). The size of the territory, including adjacent plots, is $229115.00 \mathrm{~m} 2$; the nature of valuable properties is architectural (determines the significance, important), engineering (determines the significance, important), historical (determines the significance, important), urban (determines the significance, important).

\section{Investigation and Modelling of Changes of Spatial Structure Genotype}

The aim of the research is to study in detail the peculiarities of the spatial planning structure, one of the most important valuable properties, of the former Kaunas Fortress military town and to model and evaluate the influence that the building built in the territory of a cultural heritage object will have on the expression of the aforementioned valuable property.

Theoretical background. On a most general level, the theoretical background of the research is formed by the idea of two architectural languages formulated by Christopher Alexander [4] and Nikos A. Salingaros [5]. According to the aforementioned authors, an architectural object has a form and a model that is expressed graphically, called pattern. As the form of the object is changing, the pattern can remain unchanged, and it then is the bearer of genotypic properties of the object, influencing its versatile usage. Using this idea, the research examines the spatial structure genotype of a military town, which is the most important feature of the configuration of spaces, affecting the perception and possible usage of an object.

The choice of a specific spatial genotype research methodology is based on a systematic, complex approach that sees architectural-urban spaces as a network composed of nodes and connections $[6 ; 7 ; 8]$. The space syntax method [9] based on mathematical graph model is used for modelling both architectural-urban and other (social, virtual, etc.) networks. The most important thing when it comes to architectural research is the concept of the centrality of a graph node (it may be street space, public space, urban axis, etc.) which allows to distinguish parts of the system that are the most important from different points of view. Space Syntax Methodology (Bill Hillier, "Social Logic of Space") is chosen as it is the most developed methodology that focuses on social content of spaces and is adapted to the analysis of visually perceived spatial networks - specifically, a visual graph analysis is performed. During the research, the entire territory of the military town is divided into visual cells of $5 \times 5 \mathrm{~m}$. The model based on the calculation of their centrality is used as the basis for the study.

The classical methodology, when it comes to the analysis of visual graph of space syntax [10], is supported, suggested and tried out by J. Peponis when studying the buildings using the modification of the aforementioned methodology, which links the space syntax rates with the cognitive structure of the system [11]. Obtained rates and their meanings are described in more detail by presenting the results of the research.

Based on the aforementioned models and methodologies, the research looked at the way that the spatial genotype of the entire military district of the former Artillery Division (including the part that belonged to the Lithuanian Armed Forces) has changed from the day it was built until nowadays and how it would be changed by the emergence of an auxiliary building.

Methodology and work processes. The following graphic materials was used for the research:

- Plan of military town of department of artillery and aeronautics of Aukštoji Panemunè, 1912, РГВИА. ф.13148, оп.1. д.3647 [12];

- The plan created in 1930 of officer courses of 
TABLE 1

The valuable properties of the site and the elements recorded in the Register of Real Heritage [created by authors]

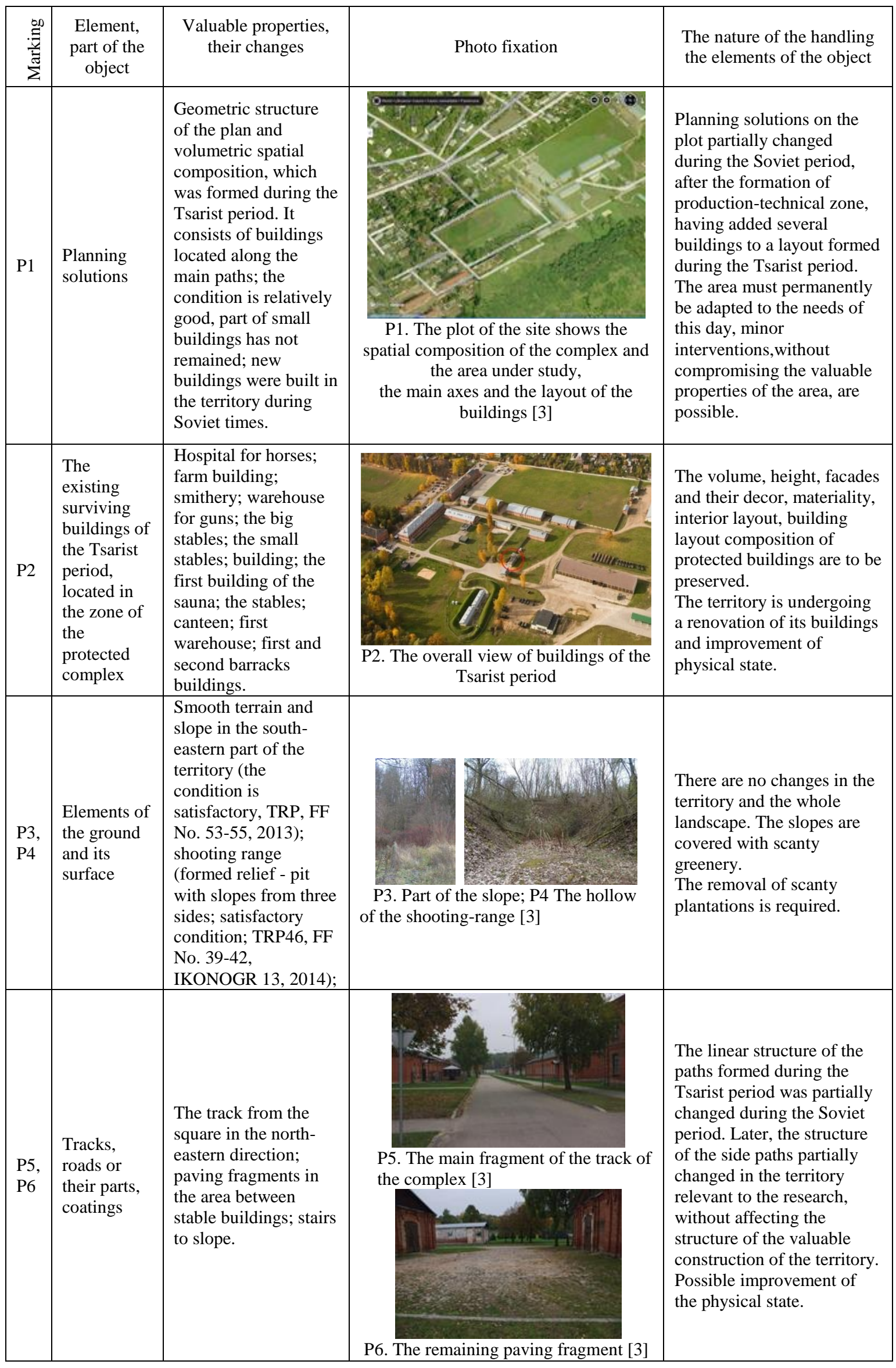




\begin{tabular}{|c|c|c|c|c|}
\hline P7 & $\begin{array}{l}\text { Greeneries } \\
\text { and } \\
\text { plantations }\end{array}$ & $\begin{array}{l}\text { The nature of the } \\
\text { afforestation of the } \\
\text { north-west and south- } \\
\text { eastern sides of the } \\
\text { square with double } \\
\text { rows of deciduous } \\
\text { trees; fragments of a } \\
\text { tree avenue in } \\
\text { Kareiviniu St., in a } \\
\text { section from the } \\
\text { square towards } \\
\text { Vaidotas St. }\end{array}$ & $\begin{array}{l}\text { P7. Valuable complex greeneries have } \\
\text { survived [3] }\end{array}$ & $\begin{array}{l}\text { There are no valuable } \\
\text { plantations or greeneries } \\
\text { remaining in the area } \\
\text { relevant to the research. }\end{array}$ \\
\hline
\end{tabular}

Analysis of the current state of the objects that do enter the territory

TABLE 2

of the protected complex and the description of repair works [created by authors]

\begin{tabular}{|c|c|c|c|c|}
\hline 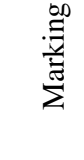 & $\begin{array}{l}\text { Element, } \\
\text { part of the } \\
\text { object }\end{array}$ & $\begin{array}{l}\text { Current state of the } \\
\text { object and possible } \\
\text { changes }\end{array}$ & Photo fixation & $\begin{array}{c}\text { The nature of } \\
\text { the handling the } \\
\text { elements of the } \\
\text { object }\end{array}$ \\
\hline P8 & $\begin{array}{l}\text { Spatial } \\
\text { planning } \\
\text { structure } \\
\text { of the } \\
\text { farming- } \\
\text { technical } \\
\text { zone }\end{array}$ & $\begin{array}{l}\text { Structure of the plan } \\
\text { and volumetric spatial } \\
\text { composition, which was } \\
\text { formed during the } \\
\text { Tsarist period. } \\
\text { It consists of } \\
\text { warehouses, garages, } \\
\text { auxiliary buildings (the } \\
\text { physical condition of } \\
\text { which is good and/or } \\
\text { relatively good); the } \\
\text { spaces and paths formed } \\
\text { during Soviet times do } \\
\text { not correspond to the } \\
\text { spatial plan composition } \\
\text { of the Tsarist period. }\end{array}$ & $\begin{array}{c}\text { P8. General overview of the farming-technical } \\
\text { zone [authors photo] }\end{array}$ & $\begin{array}{l}\text { In the farming - } \\
\text { technical or } \\
\text { technical park } \\
\text { zone, renovation } \\
\text { and } \\
\text { reconstruction } \\
\text { works are } \\
\text { possible. There } \\
\text { are no valuable } \\
\text { properties in } \\
\text { this area. }\end{array}$ \\
\hline
\end{tabular}

Vytautas the Great and districts of the Military School. Storage location - LCVA (Office of the Chief Archivist of Lithuania). Taken from N. Steponaityte' personal archive [13];

- Data from Open GOS (buildings and roads). The latter data formed the basis for the information of the historical spatial plans [14].

As already mentioned, the whole territory of the cultural heritage object is examined as one complex which can be accessed during special tourist-visitor programs, regardless of the fact that the territory is currently divided between several owners.

To transform GIS data into dxf format ArcGIC software is used. Further studies were performed using the DepthMap, a program for spatial syntax analysis.

While converting the plan of open spaces into a graph, the entire territory was covered with a grid of $5 \times 5$ meters, dividing the territory into visual cells of 25 square meters, which turned into graph nodes. The graph nodes were connected to one another only when they could be seen from one another.

During the analysis of the visual graph, the indicators, that describe the cognitive structure of space and allow to evaluate its changes, were obtained and used for modelling:

- Connectivity is the number of nodes visible from the node.

- The area visible directly from each cell (Direct purview $(D P)=$ connectivity +1$) * 25 m^{2}$ ). This rate allows to compare systems of the same size or system changes without changing the size of the visible open space. As one or several buildings built in Panemunè military town would not change the overall layout of the site very much, this rate can be used but its normalization would further increase the accuracy of the study.

- Relative directly visible area (Relative purview) is the ratio between the direct purview and the area of open spaces of the entire object. This rate performs the normalization of the numerical value of the field that is directly visible.

- The closest distance from each cell to all the other cells that is not affected by the presence of other buildings in the territory (Metric mean straight line distance)

- The shortest distance from each cell to all other cells, that is affected by distortions of visual 
boundaries formed by buildings (Metric mean shortest path distance)

- The relative elongation of the shortest paths from every cell to all the other cells (Path elongation = DepthMap metric mean shortest path distance - DepthMap metric mean straight line distance). As in the previous case, this indicator normalizes the values of the previous two indicators, making it possible to compare systems of different sizes.

- The average number of turns that needs to be done while moving from each visual cell to all the other cells (The average number of turns needed to reach other tiles or Mean turns = DepthMap visual mean depth-1). According to the space syntax theory, changing the direction of movement is one of the most important steps in shaping the mental map of the environment and orienting in it.

- Path length in meters from one change of direction to the next (Path length per turn = mean metric path distancelthe mean number of turns for each tile).

- The cognitive framework consists of ten percent of the visual cells that have the largest direct purview meanings.

- Having determined the aforementioned rates, coefficients of differentiation and distribution were calculated, which can be considered as generalized numerical rates of visually perceived space genotype - its "fingerprint". The differentiation is calculated by dividing the average DP value of the cognitive framework by the average DP value of all cells. The higher the rate, the more different the cognitive framework actually is from the overall of the rest of part of the system when it comes to the possibilities of visibility. The distribution is calculated by dividing the average number of turns of cognitive framework cells from the total number of turns. The higher the value obtained, the greater the difference between the cognitive framework and the average visibility of the remaining visual cells from any point of the system; the latter is measured by the number of turns.

At the end of the study, a comparative table was created with the maximum, average and minimum values of all the aforementioned rates. The wider explanation is provided by describing the results of the research.

\section{Results: Situations of 1912, 1930, 2016 and a forecast. Situation of 1912}

Maximum area of directly visible visual space $80925 \mathrm{~m}^{2}$, average $-46716 \mathrm{~m}^{2}$, minimum $-150 \mathrm{~m}^{2}$. The total area of empty space without buildings in the territory is equal to $6963 \times 25-174075 \mathrm{~m}^{2}$. Although the best way for the established rate to reveal the specifics of the object under study would be to compare it to other objects, it is now possible to say that the territory of the military town is of high visibility and the layout forms "perforated" walls that do not reduce visibility too much. It is interesting that the cells that have the biggest visual values are located in a square that was formerly used from trainings. Essentially, this is due to the aforementioned layout of the square, which allows to see not only two main axes, but also spaces behind the buildings - a specific feature of the local architectural-urban genotype (Fig. 5).

The relative area of the directly visible space is counted by dividing the directly visible area of every point from the total area of free space. The maximum value that was obtained is 0.46 , the average one is 0.27 and the minimum -0.0009 . This means that 46 percent of the whole territory can be seen from the points that are marked in red; on average, 27 percent of the territory are visible from each point. Thus, the territory, as already mentioned, is clearly seen from any position (Fig. 6).

Figure 7 shows the overall distance that the points can reach (each point from all the other points) in meters. It only evaluates the configuration of territorial boundaries and disregards the buildings that are in it that may limit the movement. Compared to Figure 8, which shows the shortest distances, that evaluate the boundaries for movement that are formed by buildings, instead of straight lines, this rate allows to evaluate the level of spatial transformation created with a specific layout of buildings. It is also worth noting that, regardless of the plan of asymmetrical territorial boundaries, the area with the best accessibility is in the former training area.

When comparing the following pictures, it is evident that the buildings slightly transform the original uncovered space.

This rate is calculated by comparing the distance of a straight line with the real shortest distance (Path elongation $=$ DepthMap metric mean shortest path distance - DepthMap metric mean straight line distance) / (DepthMap metric mean straight line distance). The rate generalizes the rates shown in figures 9 and 10. Its maximum value is 0.105 , the average one is 0.02 and the minimum -0.0008 . This means that the maximum deviation from a distance of a straight line when it comes to this territory is 10 percent. Interestingly, the maximum elongation is typical of points of visual field located at the rear facades of the buildings - the representative and auxiliary or household building spaces are separated without using any additional means (Fig. 9).

Maximum value of average number of turns, moving from each cell to all the others, is 2.39 (it is 


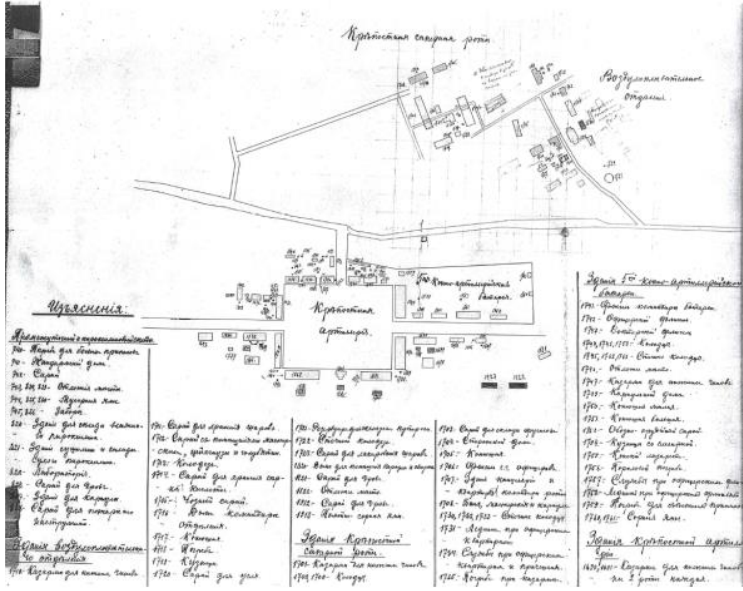

Fig. 4. Plan of military town of department of artillery and aeronautics of Aukštoji Panemunè, 1912 [1; РГВИА. ф.13148, on.1. д.3647]

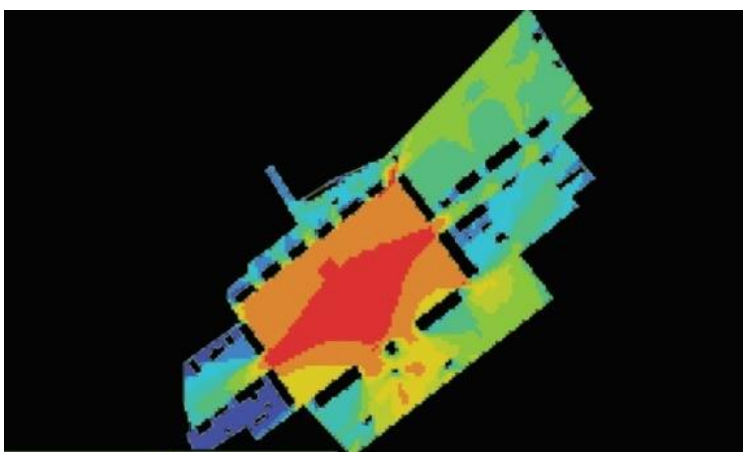

Fig. 5. 1912, directly visible area (direct purview). Explanation: Color red indicates maximum values, color blue minimum values [made by author K. Zaleckis]

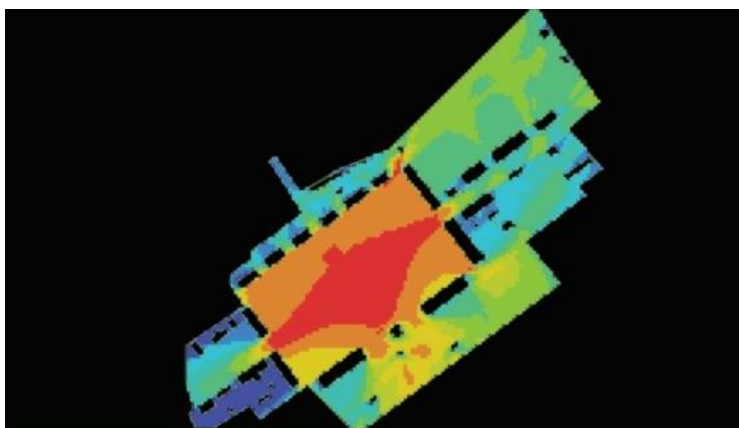

Fig. 6. 1912, relative directly visible area (direct purview). Explanation: Color red indicates maximum value, color blue minimum ones [made by author K. Zaleckis]

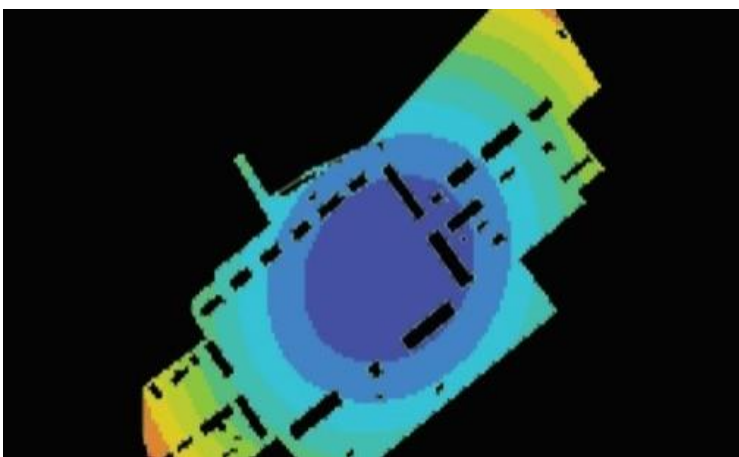

Fig. 7. 1912 Average distance of the straight line in meters. Explanation: color red indicates maximum values, color blue - minimum values [made by author K. Zaleckis] not a whole number because the rate is calculated by dividing the sum of turns necessary to reach each point from any point from the total number of points). If compared to the other objects investigated using the Space Syntax Methodology, the military town in question is a very shallow structure, which shows a possible close integration/interaction between the functions of certain spaces in this town and a high degree of visual integration (Fig. 10).

The rate is calculated by dividing the average distance between the points from the average number of turns (Path length per turn $=$ mean metric path distance / the mean number of turns for each tile). The maximum value that was obtained is 496 metres; the average value is 332 metres and the minimum - 136 metres. It is important to emphasize that this is an average distance, i.e. it is summed and divided from the number of graph connections for each point-cell, and not the real maximum and minimum distance. In the first case, it would reach about 750 meters - i.e. the length of the longest axis of the object, in the second case - about 15 meters, i.e. the length of the distance between some buildings and the territorial boundaries. These rates will be important when modelling the changes of the object under study in the course of history; it would make it possible to compare the Panemune military town with other similar objects of Kaunas Fortress and to determine its unique characteristics (Fig. 11).

The cognitive framework of the territory consists of 10 percent of visual space cells that have the greatest values of directly visible spaces (Direct purview). The unique property of town genotype is a cognitive framework that forms a rhombus shape, whose configuration and domination are determined by a perforated perimeter layout and good visibility from each space (Fig. 12).

Two summarized rates of visually perceived space genotype are the coefficients of differentiation and distribution.

Coefficient of differentiation (mean DP overview / mean DP all $)=74383 / 46717=1.592$.

The greater the value of differentiation, the more different the cells making up the cognitive framework are in comparison to the rest of the visual cells.

Coefficient of distribution (mean turn number for overview /mean turn number for all nodes) = $0.587 / 0.822=0.714$.

The higher the value of distribution, the greater the difference between reach/accessibility/proximity from any given point to the cognitive framework and the average point, measuring by changes of direction-turns.

\section{Situation of 1930}

Maximum area of directly visible space is $81325 \mathrm{~m}^{2}$ (it increased compared to 1912), the average area 


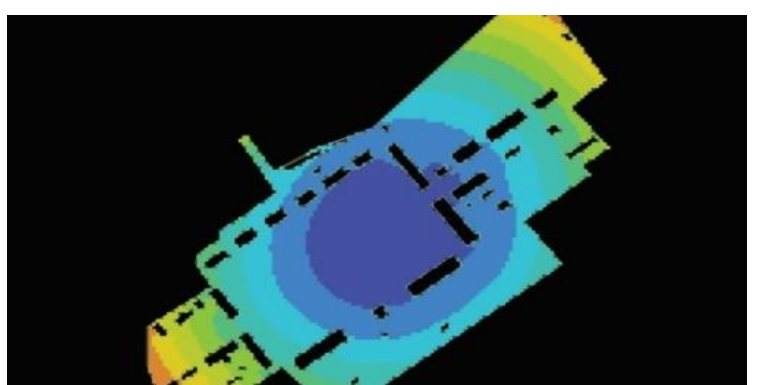

Fig. 8. 1912 Average shortest distance in meters. Explanation: Color red indicates maximum values, color blue - minimum values [made by author K. Zaleckis]

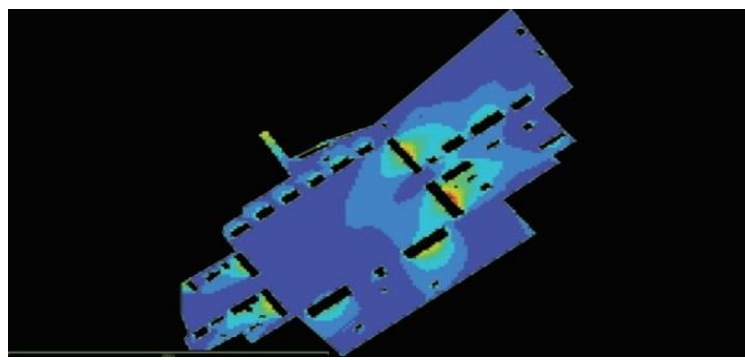

Fig. 9. 1912 Path elongation. Explanation: Color red indicates maximum values, colour blue - the minimum ones [made by author K. Zaleckis]

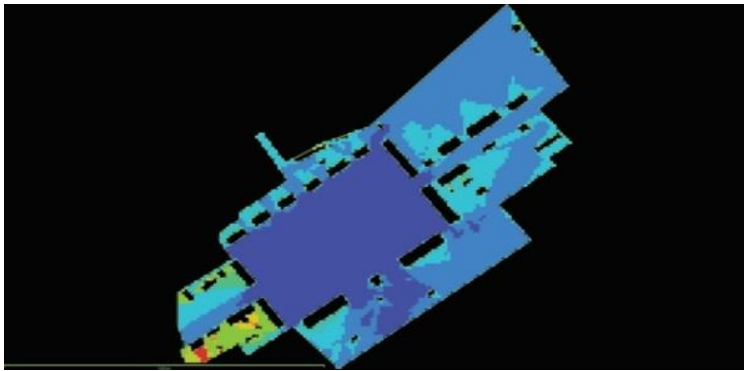

Fig. 10. 1912 Average number of turns to reach all points from any point. Explanation: Color red indicates maximum values, colour blue - minimum values [made by author K. Zaleckis]

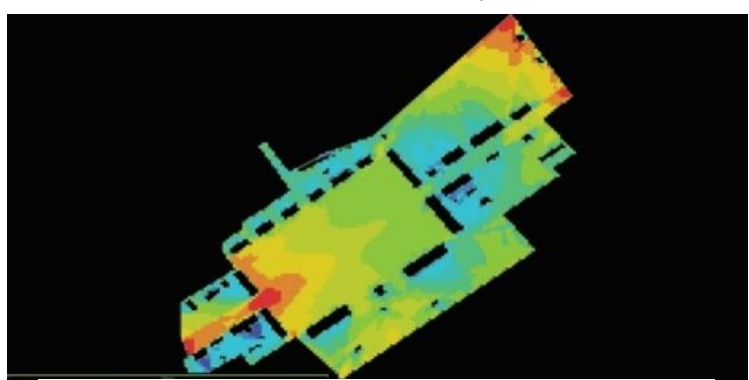

Fig. 11. 1912 Average length of a straight line between the turns. Explanation: Color red indicates maximum values, color blue - minimum values [made by author K. Zaleckis]

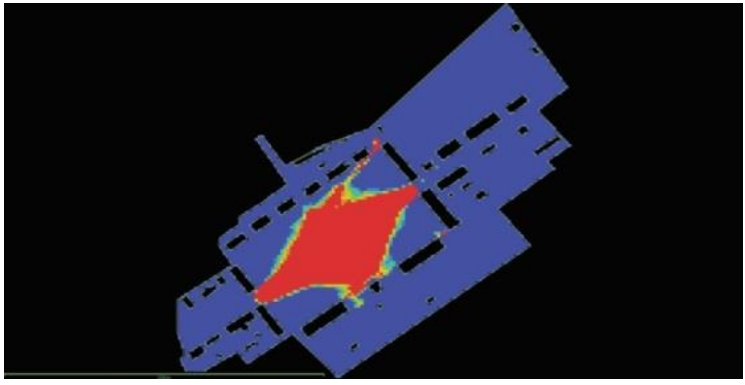

Fig. 121912 Cognitive frame of the territory (marked in red) [made by author K. Zaleckis]

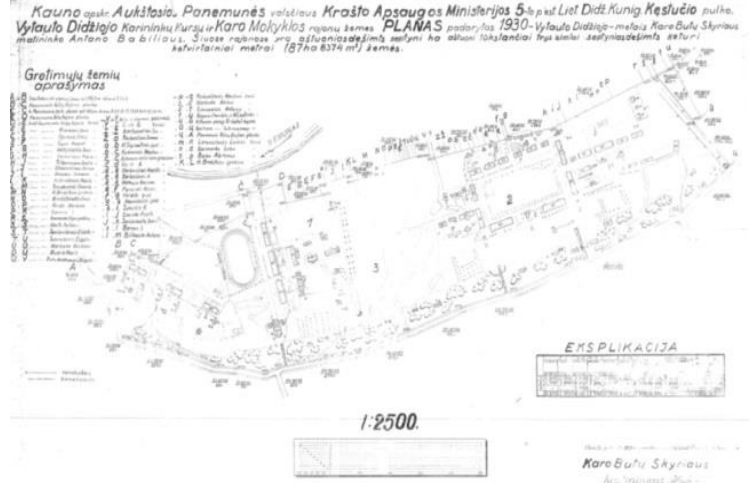

Fig. 13. The plan created in 1930 of officer courses of Vytautas the Great and districts of the Military school. Storage location

[19; LCVA (Office of the Chief Archivist of Lithuania).

Taken from N. Steponaityte' personal archive]

- 44499 (slightly less than the previous situation), the smallest area - 150 (remained the same). The total area of an open territory without buildings decreased because of the construction of new buildings. It is $6918 \times 25-172950 \mathrm{~m}^{2}$. The differences between the rates are not very significant, but the normalized rates will allow to evaluate them more accurately.

The maximum rate of a relative directly visible area is 0.47 , the average value is 0.26 and the minimum value is 0.0009 . It shows that 47 percent of the territory can be seen from the visual points with the highest values of direct visibility, when on average 26 percent of the area in question can be seen from each point. In both cases, when comparing the situations of 1912 and 1930 the change is one percent respectively.

The distribution of a metric straight line and the absolute values of the shortest distance in the territory does not reveal any differences when it comes to the visual comparison between the situations of 1912 and 1930.

The maximum value of straight path elongation 0.108 , the average value is 0.02 , and the lowest is 0.009 . This means that the maximum elongation of the road is 10 percent and the average is two percent. The rates have not changed substantially compared to the previous situation.

The maximum calculated average value of turns when they move from each point to all the other points remains the same, i.e. 2.39, if compared to the situation of 1912.

Maximum average length of a straight section is $493 \mathrm{~m}$ (decreased by 3 meters in comparison with 1912), the average length - $324 \mathrm{~m}$ (decreased by 8 meters) and the minimum is $136 \mathrm{~m}$ (remained unchanged).

As in the situation of 1912, the cognitive framework of a territory in question consists of a rhombus in its centre (former training ground). Coefficient of differentiation 74704 / 44999=1.660. Coefficient of distribution $-0.581 / 0.843=0.689$. 
A slightly more significant change is shown by the coefficient of distribution, which means that the cognitive framework has become slightly less accessible compared to the previous situation, however the change is not substantial.

Summing up the situations of 1912 and 1930, it can be said that the visual-cognitive genotype of the area under study remains unchanged, and the insignificant changes in the rates that describe it, probably together with the situation of 2016, further define certain indicative genotype changes.

\section{Situation of 2016}

The maximum value of a directly visible area is $76575 \mathrm{~m}^{2}$, the average value is $44467 \mathrm{~m}^{2}$, the minimum $-225 \mathrm{~m}^{2}$, and the total area of the territory in question is $-174375 \mathrm{~m}^{2}$. There is a slight decrease in maximum and average values, but the change in both cases is about 5 percent if compared to the situation of 1912. The relative change in these rates will be revealed by further research.

The maximum value of a relative directly visible area is 0.44 , the average value is 0.26 , the minimum value is 0.0012 . This indicates that during the Soviet period and in the interwar period the maximum area that can be directly visible in the territory in question shrunk by 2 percent, and the average visible area by 1 percent. As already mentioned, it is not a major change that indicates the mutation of genotype. Instead, it is a slight extension of variability. The latter statement can be based on space dimensions defined by Bryan Lawsan according to the nature of its social use: personal, social and common space. The latter can also be categorized according to the visual distance of recognizing another person (Bryan Lawson, "The Language of Space"). In all cases, changes of the characteristics of spaces do not transfer them from one category to another.

The visual assessment of the results of research related to the straight line and the shortest metric distance revealed that the changes are unnoticeable if compared with the situation of 1912 and 1930.

The maximum coefficient of the elongation of the shortest path in the territory, if compared with the undeveloped territory, is 0.101 , the average 0.02 , the minimum -0.008 . This shows that, despite some minor changes in the rates discussed previously, the degree of initial transformation of the spatial structure of the territory from the open space to the space limited by buildings remains unchanged. The average maximum number of turns while moving from each point to all the other points in 2016 is 2.15 . The maximum value of a straight line between the turns is 507 metres; the average value is 330 metres and the minimum - 128 metres. As in previous cases, a certain slight change, compared with the situation of 1912 , can be noticed,

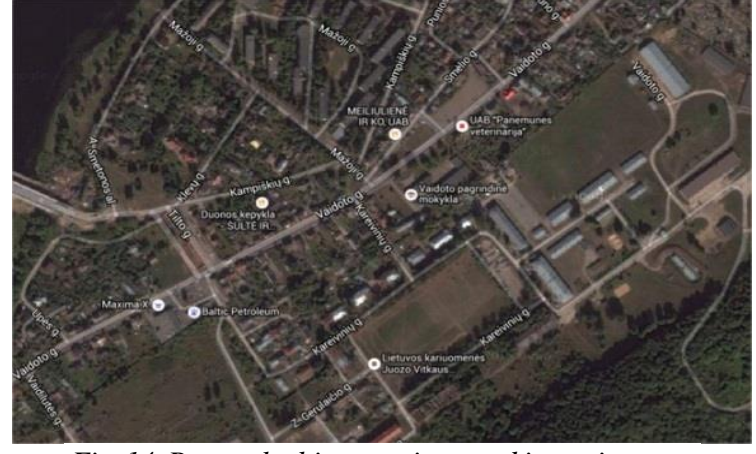

Fig. 14. Research object: territory and its environment in 2016 (google.com/maps) [20]

but it is not crucial to both the genotype and the urban phenotype and, according to Bryan Lawson' spatial characteristics, that are important to its use in a social context, it did not create a significant change.

The cognitive framework of the territory remains unchanged compared with 1912 and 1930.

The summarizing coefficients of differentiation and distribution also do not show any significant changes in the territory, and if the attention is paid to micro changes - they become even closer to the primary situation of 1912 (if compared with the situation of 1930). Coefficient of differentiation = $70537 / 44648=1.580(1912-1.592,1930-1.660)$. Coefficient of distribution $=0.599 / 0.821=0.730$ (1912 - 0.714, $1930-0.689)$.

Predicted situation. The predicted situation differs from the existing one in one newly designed building. When the aforementioned building was built in the territory relevant to the research of a directly visible area, the biggest value would be equal to $76550 \mathrm{~m}^{2}$, the average $-43957 \mathrm{~m}^{2}$, the minimum $-200 \mathrm{~m}^{2}$, and the total area of a territory under investigation would decrease to $6920 \times 25$ $173000 \mathrm{~m}^{2}$. Compared to the current situation, the changes are insignificant and even smaller than the ones that occurred in both 1912-1930 and 1930-2016.

The relative radius of a clearly visible territory after the construction of a new building will not essentially change compared to the situation of 2016. Its maximum value would be -0.44 (unchanged), average -0.25 (decrease by 0.01 ), minimum -0.00111 (decrease by 0.0001 ). This suggests that the average area of the direct visual field that can be seen in the territory was reduced by one percent. This is a small change which, given the fact that the cognitive framework of the territory is formed by visual cells of the territory with the highest values in regards to directly visible field that are at the centre of the territory, could be allowed to be bigger.

The visual assessment of the results of research related to the straight line and the shortest metric 
The most significant changes that occurred and that are thought to occur later on in regards to the rates of visual genotype of an analysed territory [created by authors]

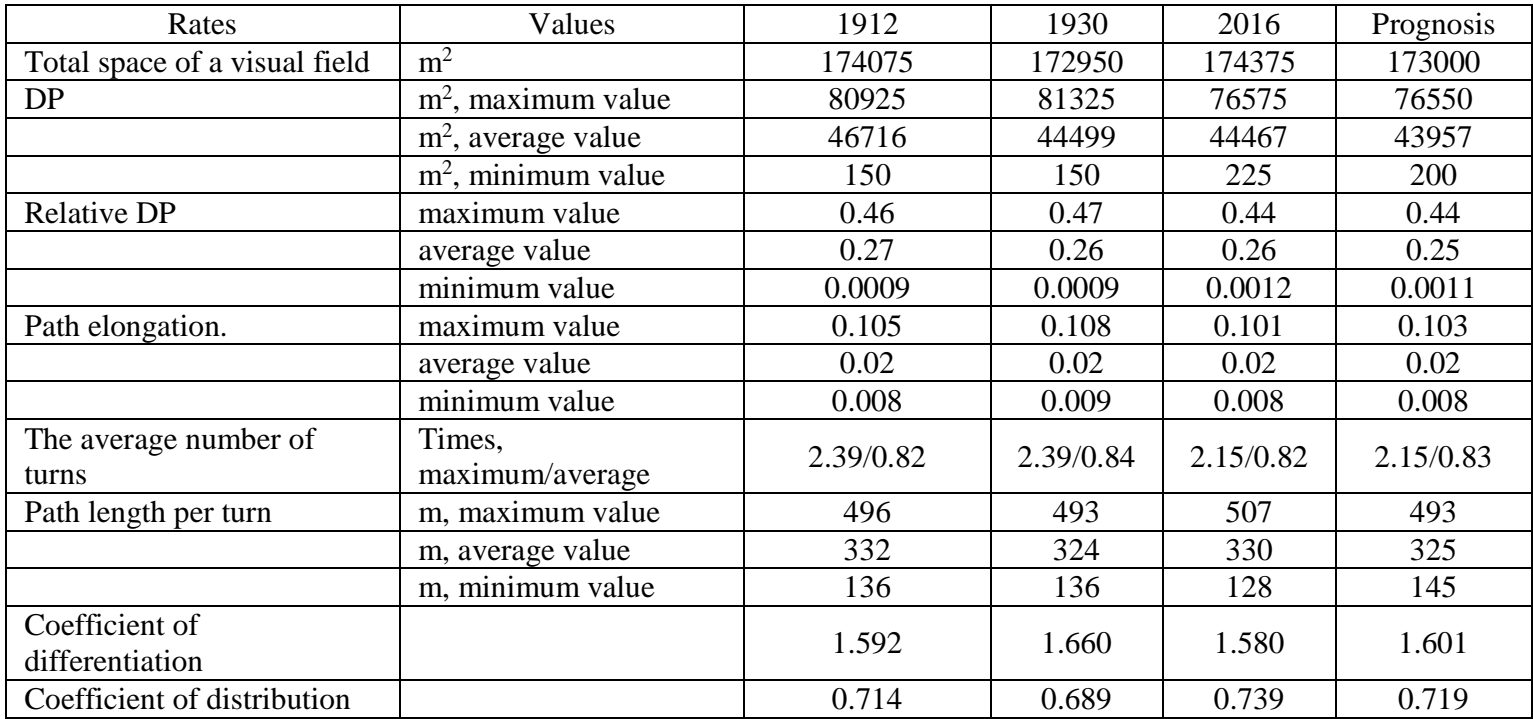

distance revealed that the changes are unnoticeable if compared with the situations of 1912, 1930 and 2016.

Upon the construction of the new building, the maximum value path elongation in the area under study would be 0.103 , the average - 0.02 , the minimum - 0.008. The numbers reveal that only the path from the "deepest" - i.e. most remote, least visible parts of the territory to all the other visual cells could become longer by a tenth of a percent. In the predicted situation, the average maximum number of turns while moving from each point to all the other points would remain the same as it was in the situation of 2016, i.e. 2.15.

The maximum average length of a straight section between the turns having built a new building in the area under study would be $493 \mathrm{~m}$, the average $-325 \mathrm{~m}$, the minimum $145 \mathrm{~m}$. If these rates were compared with the situation of 2016, the change would be from 5 to 17 meters. Having in mind the size of the space (the longest axis is about 750 meters) and the relative proportion of the changes compared with the values obtained in meters, this is only a slight change. However, the changed rates are approaching the situation of 1930 (493/324/136).

The map of cognitive framework, if we compare it with the situation of 1912, 1930 and 2016, does not show any changes - it is formed by a rhombus in the centre of the territory.

Estimated territorial differentiation rate $=$ $70370 / 43957=1.601$

Estimated distribution rate $=0.599 / 0.833=0.719$

They both fit into the limits set by slight fluctuations of previous rates.

Table 3 summarizes the data of four situations of territory under investigation.
Summarizing the data of the research presented in the table it can be concluded that the visual genotype of the analysed territory is essentially has not changed from the beginning of its formation. Slight micro changes do not affect either the genotype or the phenotype, and are unnoticeable to the observer moving around the territory. This statement can be supported by different theories and models:

- Nikos A. Salingaros' researches of differences when it comes to scales perceived by people [5], in which he discusses how objects of different scale, or, in our case, of different size, are perceived, when their relative difference exceeds the number $e-2.17$. The quantitative changes of the genotype that were found do not come close to this rate.

- On the grounds of the conception of generalized (that are not divided into visual cells, as it is the case with this study) perceptual sequences of visual spaces (serial vision) formed by buildings, as formulated by G. Gullen (Concise Townscape). According to the aforementioned theory, the perception of an urbanized area takes place while moving from one space to another. In this case, what is the most important is the sequence of the most generalized spaces, their sizes and visual relations with each other (i.e. visibility). The quantitative changes of spatial structure that were found do not exceed several percent and does not change the visually perceptible properties of the spatial structure.

- Bryan Lawson's theory on the language of space (The Language of Space) and the relationship between space dimensions and their social uses. According to the aforementioned theory, open (e.g., Urban) spaces, depending on their 
distances, can be divided into private, social and public spaces. The latter can be divided according to another person's face recognition distance. According to this model, the changes of spatial dimensions are very slight and thus do not change their nature.

\section{Discussion}

Architectural and urban cultural heritage could be seen as an important formant of built environment from many both theoretical and practical perspectives, e.g.:

- Michael Cole in his theory of cultural-historical psychology proposes concept of outer collective consciousness as an important formant of cultural behaviour [15]. Collective consciousness, according to him is stored and transferred through cultural artefacts which could be described as ideal and material at the same time. From this point of view cultural tangible heritage could be seen as an important cultural artefact.

- If, according to theory of semiotics, build environment is treated as a cultural text, then objects of cultural heritage could be seen as a symbols which make history readable or living now.

- In general terms, from th perspective of genius loci cultural heritage could be seen as an important assest of urban identity.

- If cultural dimension of sustainable urban development is considered - one of the straight forward ways to address it goes through integration of cultural heritage into contemporary urban fabric.

- Immovable cultural heritage could be seen as an important immovable property market layer and catalyser of neighbouring property values [16; 17]; etc.

The above mentioned theories and approaches illustrate the multifunctional potential of tangible heritage which might be utilised only if heritage is actively used in existing contemporary contexts. Such a need quite often creates a contradiction between need to preserve and need to adopt to new functions and changes. As the main tool to assure preservation of cultural heritage in Lithuania is seen a list of its valuable features, e.g. spatial structure, architectural composition, elements of deco, etc. The problem lays in the fact that the above mentioned valuable features are just named thus allowing a big freedom of interpretation if certain valuable features is affected or not in certain situation. Quantitative evaluation of the valuable features and focus on its genotype instead of phenotype might be seen as more objective ways to evaluate transformation and evolutions of historical architectural objects. Different approaches could be mentioned and tested in this situation, e.g. fractal analysis of the facades and spatial structures [18], mathematical description of patterns of architectural forms [5], etc. Space Syntax based approach, which was demonstrated in the presented research, at least in a case of analysis of spatial structure, proves it effectiveness in a precise case and big potential for further exploration.

\section{Conclusions}

1. The urban structures of territories of military building complexes formed until the World War I; only the southwestern part, where the Military School was established in the interwar period, was redesigned and the first stadium for military use in Lithuania as well as a new military school building were built. In Soviet times, large new buildings were built in various parts of the territory. Then, in the north-eastern part of the territory in question, a lot of storage facilities of different volumes for large vehicles were built, and they still are at the same place to this day. The farmingproduction and administrative-residential zones have formed.

2. During the study of the layout of the territory, two morphological zones of different periods were distinguished with different morphological types of layout, where the layout of the buildings built in the Tsarist period is clearly geometrically structured, the layout of buildings is strict and linear, and the structure of the layout formed during the Soviet times is free, formed without regard to the previous layout.

3. The territory of the battalion is divided into two different functional areas: administrative-residential and technical park. It clearly defines and indicates the functional purpose of those buildings, depending on in which of the functional zones of the territory they are. Garages, workshops, warehouses, gas station and other objects are in the technical park area. Administrativeliving zone of the battalion is dedicated to trainings, accommodation, conferences and other objects of public-administrative purpose.

4. The visual peculiarity of the territory is determined by the architectural expression of buildings of different periods: materiality, volumes, decision related to colour, etc. The results of the research suggest that the physical expression of the building that will be constructed (materiality, decision related to colour) should match the buildings that were renewed during the period of independence. The physical state of buildings of the Tsarist period is either good or average. Buildings are being renovated and maintained, without compromising their valuable properties. The physical state of buildings of the Soviet period is good, with the exception of a few buildings, as their state is only average.

5. The valuable properties of the territory and the nature of their handling: the existing remaining layout of buildings of the Tsarist period is valuable and registered in the Register of Real Heritage of the Republic of Lithuania. The renovation of buildings and an improvement of their physical state is taking place in this territory; paths, roads or their parts. 
6. The investigated area is characterized by an interesting spatial structure genotype - despite of the square and street junction model often found in urban structures, which, at first sight, is typical of the territory; its spatial structure is composed of closely interconnected spaces that can be seen very well when looking from one to another.

7. The spatial cognition framework of the territory is centred on the "rhombus" shaped territory of the former ground for training - such a focus is determined by the perforated perimeter of the square and street. It is an exceptional property when it comes to this territory that is unlikely in other urban complexes.

8 . In the territory in question, using only minimal means (basically, only the layout of buildings) representative, household or more "private" spaces are separated - it is a good example of masterful planning.
9. The specific cognitive framework configuration of the territory is determined by perimeter layout with spaces between buildings. It is very important to preserve the latter property of layout in the future, as any change can cause a modification of spatial structure genotype.

10. The study of the territory was carried out taking into account its historical boundaries and its cognitive/architectural potential, which, as the territory is shared by several users, is not readily accessible to outsiders. We recommend the management of Juozas Vitkus Engineering Battalion to take an active part in the activities of the Kaunas Fortress Regional Park and to provide visitors with a chance to get to know the part of the territory of Panemune military town that it manages, during sightseeing tours.

\section{References}

1. Инвентарные планы. Постройки в Понемон. РГВИА, ф.13148, оп. 1, д. 3647.

2. План строений конно-артилерийской батареи с показанием предпологаемого расположения конюшни. 'KAA, f. 465, ap. 1, b. 292, 1. 1.

3. Register of Real Heritage of the Republic of Lithuania. Accessed online: www.kpd.lt.

4. Alexander, Ch., Ishikawa, S., Silverstein, M., Jacobson, M., Fiksdahl-King, I., Angel Sh. A Pattern Language: Towns, Buildings, Construction. Oxford University Press, New York, 1977.

5. Salingaros, N.A., Mehaffy, M.W. A Theory of Architecture. Umbau-Verlag, Harald Püschel, 2006.

6. Batty, M. The New Science of Cities. MIT Press; Reprint edition, 2017.

7. Dupuy, G. Urban Networks - Network Urbanism. Techne Press; None ed., 2008.

8. Oswald, F., Baccini, P. Netzstadt: Designing the Urban. Birkhauser Verlag AG, 2003.

9. Hillier, B., Hanson, J. Social Logic of Space (p. 90-93). Cambridge University Press, London, 1984.

10. Turner, A. Depthmap: A program to perform visibility graph analysis. Proceedings, 3rd International Space Syntax Symposium Atlanta, 2001.

11. Peponis J. Building layouts as cognitive data: purview and purview interface (p. 11-52). Cognitive Critique 6, 2012.

12. Инвентарные планы. Крепостная саперная рота. 5-ая конно-артилерийская батарея. Воздухоплавательное отделение. Крепостная артилерия. РГВИА, ф. 13148, оп. 1, д. 3647.

13. Инвентарные планы. Пороховые склады в Понемон. РГВИА, ф.13148, оп. 1, д. 3647.

14. Fragments of Kaunas' City Plan. Accessed online: www.geoportal.lt.

15. Cole, M. Cultural Psychology: A Once and Future Discipline. Cambridge: Harvard University Press, 2003.

16. Lazrak, F., Nijkamp, P., Rietveld, P., Rouwendal, J. The Market Value of Cultural Heritage in Urban Areas: An Application of Spatial Hedonic Pricing (p. 89-114). Springer, Journal of Geographical Systems 16, 2014.

17. Rudokas, K., Landauskas, M., Viliūnienė, O., Gražulevičiūtė-Vileniškẻ, I. Hedonic analysis of housing prices and development in Kaunas: heritage aspect (p. 15-27). Environmental research, engineering and management. Kaunas: KTU, vol. 75, iss. 2, 2019.

18. Ostwald, M.J. The Fractal Analysis of Architecture: Calibrating the Box-Counting Method Using Scaling Coefficient and Grid Disposition Variables (p. 644-663). Sage journals, Environment and Planning B: Urban Analytics and City Science, 2013.

19. Генеральный план расположения казарм для баталионов крепостной артилерии в им. Понемон. КАА, f. 465, ap. 1, b. $329,1.1$.

20. Scheme of the Situation in the Part of Panemune District. Accessed online: www.maps.lt.

\section{AUTHORS:}

Kęstutis Zaleckis obtained the Diploma of Architect at Vilnius Gediminas Technical University in 1991. The $\mathrm{PhD}$ in humanities was obtained at 2002 at Vytautas Magnus University and Institute of Architecture and Construction. The main research areas: regularities of influence of spatial urban structures on social, economic and cultural contents; urban history; military architecture; space syntax, fractal analysis and another quantitative method which could be combined with the qualitative research. The research results are published in more than 40 scientific publications including two collective monograph (one published by De Gruyter Sciendo), Text book on usage of Space Syntax in urban analysis, study, etc.

He is Professor and Principal Investigator of the Research Group "Cultural and Spatial Environment"at the Faculty of Civil Engineering and Architecture, Kaunas University of Technology. He is a leader of researcher in various nationals and international research projects, a member of National Commission for Cultural Heritage, co-author of three city master plans, etc. E-mail: kestutis.zaleckis@ktu.lt 
Aušra Mlinkauskienè. Obtained the_degree of Bachelor of Architecture from Vilnius Gediminas Technical University in 1995, the degree of Master of Architecture from Kaunas University of Technology in 2000, and $\mathrm{PhD}$ degree in Technological Sciences from Kaunas University of Technology in 2010. Her main research interest's area: cultural heritage, protected areas, cultural landscapes, urban structures.

She is Associated professor and coordinator for international relations at the Faculty of Civil Engineering and Architecture, Kaunas University of Technology; Scientific administrator of the Journal of Sustainable Architecture and Civil Engineering; Organiser of Study KAFe 2019 in Kaunas architecture festival (KAFe2019) and international scientific conferences; the member of the immovable cultural heritage review board and is certified cultural heritage specialist.

She has also participated in numerous international scientific conferences: Advanced Construction, Ecological Architecture, Formation of Urban Green Areas, International Scientific Conference in Iasi, etc. E-mail: ausra.mlinkauskiene@ktu.lt

Nijolè Steponaitytė. In 1972 I obtained a master's degree in architecture from Vilnius Civil Engineering Institute, now Vilnius Gediminas Technical University. Area of interest: cultural heritage, urban planning, territorial planning. She has work as a researcher in Kaunas Municipality Public Institution Kaunas Fortress Park, as well as with various companies on territorial planning projects. She is a cultural heritage expert. She publishes articles on cultural heritage in Lithuanian scientific journals. E-mail: n.steponaityte@yahoo.com

Kopsavilkums. Pētījums strukturēts trīs daḷās: vēsturiskās pilsētvides attīstības mantojuma teritorijas izpēte, pašreizējās situācijas analīze un teritorijas telpiskās struktūras izmaiņu izpēte un modelēšana. Rakstā iegūtie rezultāti parāda un atspoguḷo kultūras mantojuma objektu vērtību, sistēmas ierobežojumus un iezīmē iespējamo situācijas uzlabošanas veidu. 